UCRL-JC-122958

PREPRINT

\title{
Ceramic Waste Form for Residues from Molten Salt Oxidation of Mixed Wastes
}

\author{
R. A. Van Konynenburg \\ R. W. Hopper \\ J. A. Rard \\ F. J. Ryerson \\ D. L. Phinney \\ I. D. Hutcheon \\ P. G. Curtis \\ RECEIVED \\ MAY 021996 \\ OSTI
}

This paper was prepared for submittal to the

Materials Research Society Fall Meeting

Boston, MA

November 27-December 1, 1995

November 1995

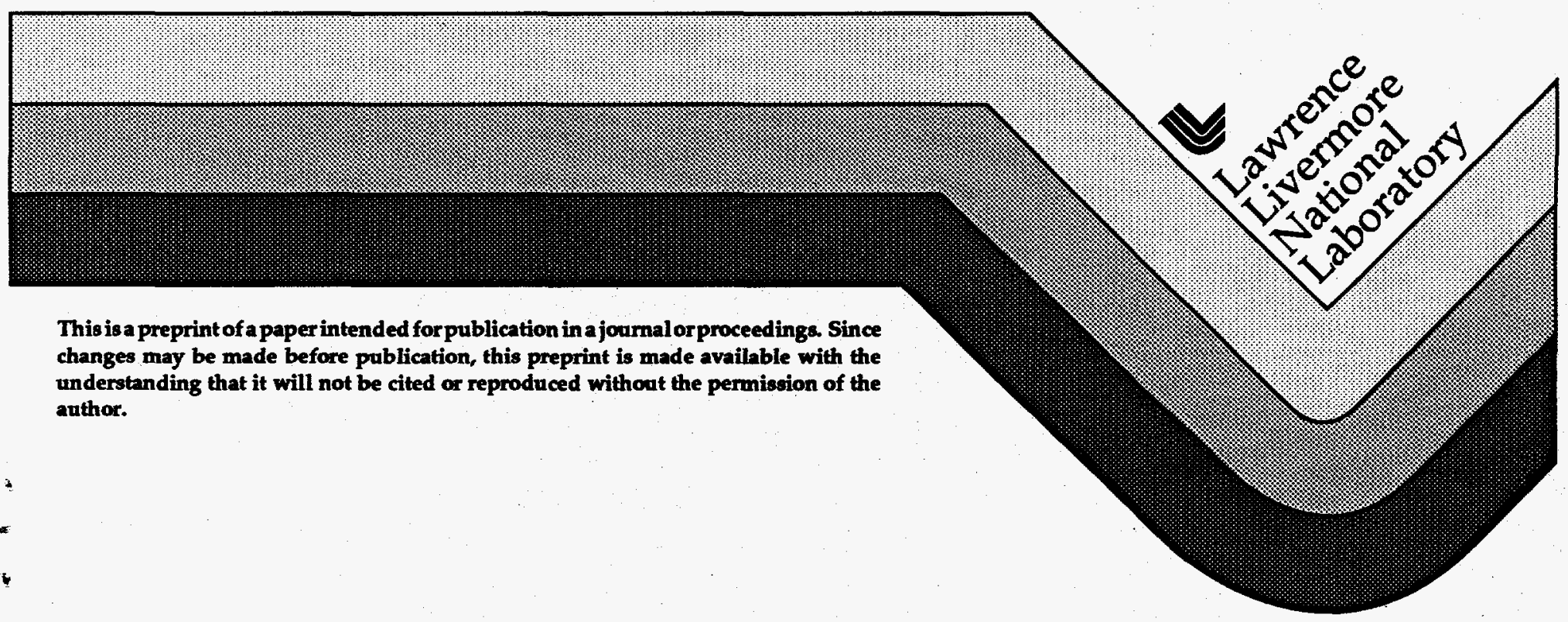





\section{DISCLAIMER}

Portions of this document may be illegible in electronic image products. Images are produced from the best available original document. 


\title{
CERAMIC WASTE FORM FOR RESIDUES FROM MOLTEN SALT OXIDATION OF MIXED WASTES
}

\author{
RICHARD A. VAN KONYNENBURG, ROBERT W. HOPPER, JOSEPH A. RARD, \\ FREDERICK J. RYERSON, DOUGLAS L. PHINNEY, IAN D. HUTCHEON, and PAUL \\ G. CURTIS \\ Lawrence Livermore National Laboratory, University of California, L-369, \\ P.O. Box 808, Livermore, CA 94551
}

\section{ABSTRACT}

A ceramic waste form based on Synroc-D is under development for the incorporation of the mineral residues from molten salt oxidation treatment of mixed low-level wastes. Samples containing as many as 32 chemical elements have been fabricated, characterized, and leach-tested. - Universal Treatment Standards have been satisfied for all regulated elements except two (lead and vanadium). Efforts are underway to further improve chemical durability.

\section{INTRODUCTION}

The U.S. Department of Energy plans to dispose of low-level, organicmatrix, mixed wastes by first decomposing the organic constituents and then incorporating the remaining inorganic material (including radionuclides and chemically hazardous elements) into final waste forms that have sufficient dissolution resistance to pass the prescribed EPA and state leach tests as well as to yield acceptable long-term performance. The radioactive final waste forms will then be emplaced in trenches at approved DOE sites as low-level radioactive waste.

The objective of the Mixed Waste Management Facility (MWMF) project at LLNL is to demonstrate alternatives to incineration for decomposition of the organics, using LLNL mixed wastes. In response to funding reductions since our first paper [1], the MWMF project has narrowed its focus to molten salt oxidation (MSO) as the first process to be demonstrated, primarily because of its potential versatility. Accordingly, we are developing final waste forms for residues from this process.

We currently plan to use three waste forms. The bulk of the residues from MSO (mineral residues or ashes) will be incorporated in a ceramic final waste form. Ceramic was chosen because of its high chemical durability and because of the capability of polyphase ceramics to accommodate a wide variety of chemical elements by ionic substitution. The sodium chloride-dominated waste stream arising from recycling of the MSO sodium carbonate processing salt (when chlorine-containing wastes are treated) may be mechanically incorporated into a polyethylene-based 
waste form. The constituents that volatilize during MSO processing and during sintering of the ceramic will be trapped and incorporated into sulfur polymer cement (or, possibly, into phosphate cement) as the third waste form.

The basis for the ceramic final waste form is Synroc-D, which was developed at LLNL in the early 1980s as a candidate for immobilizing Savannah River high level tank waste [2]. The original Synroc-D was composed of the mineral phases zirconolite, perovskite, spinels ( 2 types), and nepheline, as well as some residual glass [3]. The mineral phases were selected for their chemical durability, their capacity to incorporate nonradioactive simulants of the fission products and actinides as well as the inert material that dominates the Savannah River waste (primarily oxides of iron, aluminum, manganese, sodium, and silicon), and their ability to coexist in fired ceramic. The fabrication process selected at that time was hot pressing. Although Synroc-D was not chosen for incorporating Savannah River waste, it was named as the first alternate to borosilicate glass. The issues involved at that time were the lack of production experience with the hot pressing process, leading to uncertainties in cost, and the leaching behavior of those radionuclides that were present in the residual glass phase, which was not superior to their leaching behavior in borosilicate glass.

The composition of LLNL mixed wastes varies considerably, but the MSO mineral residues from processing of LLNL mixed wastes are expected to be dominated by silicon, aluminum, magnesium, zinc, calcium, and iron, all of which can be incorporated in the Synroc-D mineral phases, either as major constituents or by ion substitution. In addition, however, a large number of minor and trace elements are expected to be present, many of which have not previously been tested for solid solubility in these minerals.

In our first paper [1] we described ceramic waste form compositions that included the phases zirconolite $\left[\mathrm{CaZrTi}_{2} \mathrm{O}_{7}\right]$, perovskite $\left[\mathrm{CaTiO}_{3}\right]$, spinel $\left[\mathrm{MgAl}_{2} \mathrm{O}_{4}\right]$, nepheline $\left[\mathrm{NaAlSiO}_{4}\right]$, rutile $\left[\mathrm{TiO}_{2}\right]$, and possibly apatite $\left[\mathrm{Ca}_{5}\left(\mathrm{PO}_{4}\right)_{3}(\mathrm{~F}, \mathrm{Cl}, \mathrm{OH})\right]$. At that time, we had not included many of the possible minor and trace constituents in the waste stream, nor had we actually identified apatite in fabricated samples. W.e had selected cold pressing and sintering in air or controlled gases as the production process to be used, and we had selected $1-\mathrm{cm}$ pellets as both the developmental and the production-scale waste form configuration. These choices were made to minimize production complexity and cost, to eliminate ceramic body size scale-up uncertainties, and to provide a wasteform configuration that would minimize press size and would facilitate handling, sampling, archiving, leach testing, and reworking (if necessary).

Since that time, we have investigated the incorporation of a larger suite of elements in experimental samples, changed some starting materials and details of ceramic processing, studied volatilization of additional elements. 
during sintering, and performed more detailed characterization and testing of the product. The results are described in this paper.

\section{CHEMICAL ELEMENTS OF INTEREST}

Beginning with the entire periodic table as a basis, there are several factors that will limit the list of chemical elements that could be incorporated into our ceramic waste form:

1. Transuranic wastes will be excluded from treatment in the MWMF.

2. Elements that are very rare or costly are not likely to be present.

3. Noble gases do not exist as solids at ambient temperatures.

4. Elements will be removed that are very soluble in water under the conditions to be used in separating MSO salt from mineral residues.

5. Elements that are highly volatile at the molten salt temperature $\left(950^{\circ} \mathrm{C}\right.$ ) or at the sintering temperature (about $1150^{\circ} \mathrm{C}$ ) under oxidizing conditions will be driven off, trapped, and put into another waste form. Application of these criteria leaves the following elements as possible constituents of the ceramic waste form: $\mathrm{Li}, \mathrm{Be}, \mathrm{B}, \mathrm{O}, \mathrm{F}, \mathrm{Na}, \mathrm{Mg}, \mathrm{Al}, \mathrm{Si}, \mathrm{P}, \mathrm{S}, \mathrm{K}$, $\mathrm{Ca}, \mathrm{Sc}, \mathrm{Ti}, \mathrm{V}, \mathrm{Cr}, \mathrm{Mn}, \mathrm{Fe}, \mathrm{Co}, \mathrm{Ni}, \mathrm{Cu}, \mathrm{Zn}, \mathrm{Ga}, \mathrm{Ge}, \mathrm{Rb}, \mathrm{Sr}, \mathrm{Y}, \mathrm{Zr}, \mathrm{Nb}, \mathrm{Mo}, \mathrm{Ag}, \mathrm{Cd}, \mathrm{Sn}$, $\mathrm{Sb}, \mathrm{Cs}, \mathrm{Ba}, \mathrm{Ln}-\mathrm{REE}, \mathrm{Hf}, \mathrm{Ta}, \mathrm{W}, \mathrm{Tl}, \mathrm{Pb}, \mathrm{Bi}, \mathrm{Ra}, \mathrm{Th}$, and U. Of these, the following are end-member constituents of our selected mineral phases: $O$, $\mathrm{Na}, \mathrm{Mg}, \mathrm{Al}, \mathrm{Si}, \mathrm{Ca}, \mathrm{Ti}$, and $\mathrm{Zr}$. Among the remaining elements, those of particular interest are those with specified leaching limits in either federal [4] or California [5] regulations: $\mathrm{Be}, \mathrm{F}, \mathrm{V}, \mathrm{Cr}, \mathrm{Co}, \mathrm{Ni}, \mathrm{Cu}, \mathrm{Zn}, \mathrm{Mo}, \mathrm{Ag}, \mathrm{Cd}, \mathrm{Sb}$, $\mathrm{Ba}, \mathrm{Tl}$, and $\mathrm{Pb}$. Note that three other regulated elements (As, $\mathrm{Se}$, and $\mathrm{Hg}$ ) are too volatile to be incorporated. Although leaching is not limited by regulation for the other elements, it is desirable to bind them tightly as well, in order to maximize the overall chemical durability of the waste form.

\section{SPECIATION OF MINERAL RESIDUES FROM MOLTEN SALT OXIDATION}

The mineral residues from MSO have not yet been well characterized, but will likely consist primarily of oxides, with some borates, carbonates, fluorides, phosphates, and sulphates. Nepheline may already form in the salt bath before it is intentionally made in the ceramic fabrication process. Ceramic firing will drive off carbon dioxide from the residual carbonates, and will cause reactions among the balance of the residues and the additive materials to form the ceramic phase assemblage.

\section{CERAMIC FORMULATION}

In recent samples, we have incorporated the following elements: $\mathrm{Be}, \mathrm{B}$, $\mathrm{O}, \mathrm{F}, \mathrm{Na}, \mathrm{Mg}, \mathrm{Al}, \mathrm{Si}, \mathrm{P}, \mathrm{S}, \mathrm{Cl}, \mathrm{K}, \mathrm{Ca}, \mathrm{Ti}, \mathrm{V}, \mathrm{Cr}, \mathrm{Mn}, \mathrm{Fe}, \mathrm{Co}, \mathrm{Ni}, \mathrm{Cu}, \mathrm{Zn}, \mathrm{Ga}, \mathrm{Sr}, \mathrm{Zr}$, $\mathrm{Mo}, \mathrm{Ag}, \mathrm{Cd}, \mathrm{Sn}, \mathrm{Sb}, \mathrm{Ba}, \mathrm{Ce}, \mathrm{Nd}, \mathrm{Gd}, \mathrm{Hf}, \mathrm{Tl}, \mathrm{Pb}$, and $\mathrm{U}$. In future samples, we 
intend to include $\mathrm{Li}, \mathrm{F}$ (as $\mathrm{CaF}_{2}$ ), Sc, $\mathrm{Rb}, \mathrm{Y}, \mathrm{Nb}, \mathrm{Cs}, \mathrm{Ta}, \mathrm{W}$, and $\mathrm{Bi}$ as well. Recipes are designed to achieve maximum loading of the waste stream into the ceramic, while not exceeding the solid solubility of the minor and trace elements in their host mineral phases or producing less than $10 \mathrm{wt}$ \% of any of the designed host phases. The latter requirement is established to ensure a robust, dominant phase assemblage in the presence of the large variety of constituents.

We intend to determine the elemental composition of each batch of residues by $x$-ray fluorescence and to write a recipe tailored specifically to it. Typical recipes for an expected average combustible waste stream would have the following major phase composition: nepheline-36 wt.\%, spinel-31 wt.\%, zirconolite-12 wt.\%, perovskite-12 wt.\%, rutile-5 wt.\%, and calcium phosphate-4 wt.\%. The waste loading for this case is limited to about $40 \%$ of the final ceramic mass by the fraction of silica, alumina, and magnesia in the incoming waste stream, which is expected to average nearly $70 \%$ of it.

The calcium phosphate phase, not a designed host phase, will form when phosphorous is present in the waste stream. Rutile acts as a chemically durable titania "buffer" to promote the formation of as much perovskite and zirconolite as are needed to account for the remaining $\mathrm{Ca}$, the $\mathrm{Zr}$, and the solute elements that are to be incorporated into these two phases. Nepheline is the intended sink for silicon and some aluminum, and the spinel is intended to account for magnesium, the remaining aluminum, and the transition metal elements.

Detailed recipes were initially based on assumed mineral hosts for the various waste stream elements. These were assigned initially from a knowledge of trace compositions of natural minerals, past experience with Synroc-D, and comparison of the expected oxidation states and corresponding ionic radii of the waste elements to those of the endmember elemental constituents of the potential host phases. When this process was carried out on all the possible constituents given above, it appeared that while most of these elements would probably be accommodated, there were some that likely would not be: $\mathrm{Be}, \mathrm{B}, \mathrm{F}, \mathrm{S}, \mathrm{Mo}$, $\mathrm{Ag}, \mathrm{Ba}$, and $\mathrm{W}$. $\mathrm{Be}$ and $\mathrm{B}$ ions are simply too small to be incorporated structurally into any of the host minerals, $F$ would be in the -1 state, which is not represented among designed host sites. " S, Mo, and W would be in their +6 states during air sintering, also not represented. $\mathrm{Ag}$ would likely be in the metallic state. $\mathrm{Ba}$ ions may be too large to fit into the $\mathrm{Ca}$ sites. These did not appear to be major problems, however, for the following reasons: $\mathrm{Be}$ is known to form a very stable oxide; $\mathrm{B}$ is not a regulated element; $F$ could probably be incorporated as fluorite $\left(\mathrm{CaF}_{2}\right) ; \mathrm{S}$ is also not regulated; if necessary, $M o$ and $W$ could be reduced to the +4 state during sintering by the use of a gas less oxidizing than air; Ag metal would likely be fairly resistant to dissolution, even at $\mathrm{pH}=5$, in the absence of strong oxidizing or complexing agents; and $\mathrm{Ba}$ has high allowable leach 
limits. We decided to determine experimentally whether any significant accommodation problems would arise, and deal with them as necessary.

\section{CERAMIC PROCESSING}

In our previous paper, we described samples prepared using two alternative starting materials: alkoxide precursors and powders composed mostly of oxides, respectively. We found that higher densities were obtained after cold pressing and air sintering using the coarser oxide powders. This counterintuitive result appears to stem from the larger amount of adsorbed gases on the finer particulates that result from the alkoxide process, owing to their much larger specific surface area. This conclusion is supported by the observation that vacuum sintering of alkoxide-based pellets resulted in much better densification. Because we prefer to avoid the greater complexity and cost that vacuum sintering would entail in the MWMF, as well as the added environmental, safety, and health burdens of organic solvents needed for the alkoxides, we have chosen to pursue the oxide powder approach. To improve reactivity during sintering of synthetic samples, we use as starting materials kaolin clay $\left[\mathrm{Al}_{2} \mathrm{Si}_{2} \mathrm{O}_{5}(\mathrm{OH})_{4}\right]$ and gibbsite $\left[\mathrm{Al}(\mathrm{OH})_{3}\right]$ for silicon and aluminum, $\mathrm{NaOH}$ for sodium, anatase $\left(\mathrm{TiO}_{2}\right)$ for titanium, and $\mathrm{Zr}\left(\mathrm{NO}_{3}\right)_{4} \cdot 5 \mathrm{H}_{2} \mathrm{O}$ for zirconium. Phosphorous is added as $\mathrm{NH}_{4} \mathrm{H}_{2} \mathrm{PO}_{4}$, potassium as $\mathrm{KOH}$, beryllium as $\mathrm{BeC}_{2} \mathrm{O}_{4} \cdot 3 \mathrm{H}_{2} \mathrm{O}$, gadolinium as hydrated nitrate, silver as $\mathrm{AgNO}_{3}$, and uranium as hydrated uranyl nitrate. The other elements are added as their oxides. Starting powders are generally $5 \mu \mathrm{m}$ or smaller in size.

The powders are wet-mixed with water for 1 hour, using a ball mill. We have found that lowering the $\mathrm{pH}$ during wet mixing, by addition of nitric acid, promotes better dispersion of zirconolite in the final ceramic, but, of course, this results in more $\mathrm{NO}_{\mathrm{x}}$ off-gassing during the calcining. Future work will evaluate the pros and cons of this approach.

After overnight oven drying at $90^{\circ} \mathrm{C}$ followed by brief dry milling, the mixed powders are rotary calcined for 1 hour at $600^{\circ} \mathrm{C}$ in air, dry-milled again, and then cold-pressed in a $12.7-\mathrm{mm}$ diameter steel die at $100 \mathrm{MPa}$. Binders and lubricants have not been used in the recent samples because of the nitric acid additions, but in the past we have used Carbowax and oleic acid. In the MWMF we will use a pelletizing machine, and appropriate binders, lubricants, and dispersants will be selected to facilitate its operation and to optimize chemical durability of the product

The pressed pellets are reaction-sintered in air at about $1150^{\circ} \mathrm{C}$ on an alumina plate. This temperature was selected to be near the solidus, as determined by differential thermal analysis, to promote rapid reaction and sintering, while simultaneously minimizing melting, which would produce undesirable slumping, reaction with the alumina, and more residual glass phase. The duration of sintering used has varied from 1 hour to 1 week, the longer times being used to promote grain growth to enable more 
accurate determination of elemental phase distributions. In the MWMF, sintering time will be optimized to produce sufficiently complete reactive sintering to give acceptable leaching performance while minimizing volatilization.

During air-sintering the following metallic elements have been observed to volatilize partially, in decreasing order of fractional loss: Tl, $\mathrm{Pb}, \mathrm{Cu}, \mathrm{K}, \mathrm{Mo}, \mathrm{Cd}, \mathrm{Ag}, \mathrm{Na}$, and $\mathrm{Zn}$. If $\mathrm{Cl}$ or unbound $\mathrm{F}$ are present in the starting material during wet mixing, several other elements are observed to volatilize during sintering as well. These results are consistent with known vapor pressures of the species likely to form under these conditions, which have been reviewed and summarized [6]. Within the MWMF project, we intend to minimize the concentrations of $\mathrm{Cl}$ and unbound $F$ by efficient separation of salts from the mineral residues, to trap the species that do volatilize, and to incorporate them in another waste form, as mentioned above.

\section{WASTE FORM CHARACTERIZATION}

Sintered pellets are measured and weighed to determine their density, which usually exceeds $90 \%$ of theoretical maximum. A typical density value is $3.0 \mathrm{~g} / \mathrm{cm}^{3}$. Mercury porosimetry indicates some connected porosity. Moderate levels of porosity are expected as a consequence of the chosen fabrication approach, and probably result in increased leaching, but we believe the performance can be made satisfactory by incorporating the regulated elements in sufficiently durable mineral phases.

$\mathrm{XRF}$ analysis of samples is performed to confirm overall composition and to detect significant volatility losses. Smaller losses are determined by condensing, collecting, dissolving, and analyzing volatilized material by ICP-OES. The results of this procedure were described above. Pellets are polished and then examined by SEM-EDS to observe the morphology of the pores, which is a good indicator of the degree of melting, to determine the uniformity of the microstructure and the completeness of reactions between the starting materials, to identify the major phases present, and to evaluate the grain sizes. After one-day sintering, pores are found to be spheroidal, with diameters in the tens of $\mu \mathrm{m}$, indicating that the sintering temperature $\left(1150^{\circ} \mathrm{C}\right)$ is above the solidus. Mixing of the starting materials is not as thorough as is achievable with the alkoxide approach, but reactions appear to be essentially complete for one-day sintering, except for small amounts of very refractory oxides. Grains are generally less than one $\mu \mathrm{m}$ in size for one-hour sintering, but achieve sizes of one to about $20 \mu \mathrm{m}$ after one-week sintering.

XRD assists in determining the completeness of reaction and in identifying the crystalline phases produced, but the complexity of the compositions often precludes unique assignment of all the minor peaks in the diffraction patterns. Electron microprobe and SIMS analyses are used to determine partitioning of elements among the phases. A small amount of STEM analysis also has been performed. 
The major crystalline phases normally identified are spinel, nepheline, zirconolite, perovskite, and rutile. Spinel is found to be the major host phase for the transition elements from $\mathrm{V}$ through $\mathrm{Ga}$, with the possible exception of $\mathrm{Cu}$, which assumes the +1 state at high temperatures. Nepheline incorporates $\mathrm{K}$. Zirconolite hosts $\mathrm{Sr}$, minor amounts of rare earths, Hf, and U. Perovskite is the major host for rare earths, and also incorporates $\mathrm{Sr}$ and $\mathrm{Pb}$. When $\mathrm{Be}$ is present, it is found either as bromellite $(\mathrm{BeO})$ or chrysoberyl $\left(\mathrm{BeAl}_{2} \mathrm{O}_{4}\right) . \quad \mathrm{Ag}$ is found as spheroidal metallic inclusions. When significant levels of phosphorus are present, calcium phosphate is observed as porous, spheroidal inclusions. The stoichiometry does not correspond to that of hydroxylapatite $\left[\mathrm{Ca}_{5}\left(\mathrm{PO}_{4}\right)_{3}(\mathrm{OH})\right]$. Possibly the phase is a phosphate glass. The known immiscibility of phosphate and silicate melts [7] would account for its spheroidal (interface-minimizing) morphology. Efforts are continuing to determine the trace composition of this phase, as well as the phase distribution of other elements.

In addition to the crystalline phases and the phosphate phase, a glassy silicate phase is also observed, as in Synroc-D. As one would expect, this phase incorporates those elements that are incompatible with available sites in the phases already mentioned: $\mathrm{S}$, Mo, and $\mathrm{Ba}$ have been found in the glass, for example. $B$ has not yet been localized, and $W$ has not yet been included in the samples. Some elements that have crystalline host phases partition to a lesser degree into the glass as well. Because the glassy phase exhibits lower chemical durability, we are making efforts to reduce its amount or to eliminate it. Approaches being studied include (1) lowering the sintering temperature to decrease the amount of liquid phase formed during sintering, (2) decreasing the silica content, since high-silica melts are known to be viscous and difficult to crystallize [8], and (3) performing a final crystallization heat treatment below the solidus temperature, as is done in the manufacture of glass-ceramics. The elimination, to the degree possible, of $B$ and $S$ during salt separation is also being pursued as a means of discouraging the formation of residual glass.

\section{LEACH TESTING}

The U.S. Environmental Protection Agency has prescribed the Toxicity Characteristic Leaching Procedure (TCLP) [4] as the test for determining whether a waste is to be classified as chemically toxic. This test involves room temperature leaching during rotary agitation for 18 hours in an acetic acid solution buffered at $\mathrm{pH}=4.93$, with a mass ratio of solution to wasteform of 20 . The sample used must be able to pass through a $9.5-\mathrm{mm}$ sieve. We have scaled this test down from the specified minimum of 100 grams of sample to our pellet size ( 1 to $3 \mathrm{~g}$ ), keeping the solution-to-waste ratio and the other parameters as specified. Quantitative elemental analysis of leachates is performed by ICP-OES and ICP-MS. The results for a recent sample of our ceramic $(\# 212)$ are shown in Table I: 


\section{Table I. TCLP Leach Test Results for Sample \#212}

Che m ic al

Element

Concentration
in Sample
(wt. $\%)$

$\begin{array}{ll}\mathrm{Be} & 0.33 \\ \mathrm{~V} & 0.063 \\ \mathrm{Cr} & 0.063 \\ \mathrm{Ni} & 0.073 \\ \mathrm{Zn} & 2.44 \\ \mathrm{As} & \text { none } \\ \mathrm{Se} & \text { none } \\ \mathrm{Ag} & 1.76 \\ \mathrm{Cd} & 0.081 \\ \mathrm{Sb} & 0.154 \\ \mathrm{Ba} & 0.099 \\ \mathrm{Hg} & \text { none } \\ \mathrm{Tl} & 1.66 \\ \mathrm{~Pb} & 0.083\end{array}$

\author{
Concentration \\ in Leachate \\ ( $\mathrm{mg} / \mathrm{l})$
}

$$
0.010
$$

0.24

$<0.05$

$<0.08$

0.81

not analyzed

not analyzed

0.06

0.03

$<0.1$

5.3

not analyzed

0.02

1.33

\author{
Original \\ TCLP Limit \\ (mg/l)
}

$\begin{array}{cc}\begin{array}{c}\text { Original } \\ \text { TCLP Limit } \\ \text { (mg/l) }\end{array} & \begin{array}{c}\text { Proposed } \\ \text { UTS Limit } \\ \text { (mg/l) }\end{array} \\ \text { none } & 0.04 \\ \text { none } & 0.23 \\ 5.0 & 0.86 \\ \text { none } & 5.0 \\ \text { none } & 5.3 \\ 5.0 & 5.0 \\ 1.0 & 0.16 \\ 5.0 & 0.30 \\ 1.0 & 0.19 \\ \text { none } & 2.1 \\ 100.0 & 7.6 \\ 0.2 & 0.025 \\ \text { none } & 0.078 \\ 5.0 & 0.37\end{array}$

Proposed

UTS Limit

(mg/l)

Note that the listed concentrations in the ceramic sample are mean concentrations based on the starting material, and do not take account of volatilization losses. UTS stands for Universal Treatment Standards $[9,10]$. Sample \#212 received a post-sintering heat treatment at $1100^{\circ} \mathrm{C}$ for 1 day and a slow cool-down, to reduce the amount of residual glass. As can be seen, this sample easily passes the original TCLP limits, and, except for $\mathrm{Pb}$ and for $\mathrm{V}$ (which is just over the limit), it also satisfies the proposed UTS limits. We have evidence that at least some of the $\mathrm{Pb}$ and $\mathrm{V}$ reside in the glass phase, and anticipate that future efforts to minimize residual glass will reduce the release of $\mathrm{Pb}$ and $\mathrm{V}$.

In addition to the TCLP test, our ceramic is also currently subject to the California WET test [5], which is more stringent, requiring that the sample pass through a $2-\mathrm{mm}$ sieve, prescribing a citric acid leachant, and setting limits on four additional elements: $\mathrm{F}, \mathrm{Co}, \mathrm{Cu}$, and $\mathrm{Mo}$. The first requirement results in much greater exposed sample surface area, and the second introduces a powerful chelating agent. Preliminary indications are that this is a very difficult test to pass, but it may not be representative of conditions in landfills. It is currently under reconsideration by the state Department of Toxic Substances Control. 
We have demonstrated the bench-scale fabrication of a polyphase ceramic waste form for incorporating mineral residues from molten salt oxidation treatment of mixed wastes. Individual samples of the ceramic have been made containing as many as 32 chemical elements, including 15 of the 18 elements having leach limits assigned by U.S. or California state regulations. With the exception of two elements (lead and vanadium), the ceramic satisfies the proposed federal Universal Treatment Standards. We expect that reduction in the amount of residual glass in the ceramic will make it possible to satisfy the limits for these elements as well. Continuing efforts will be made to satisfy state requirements as they become more certain.

Other planned work includes matching the speciation of the waste form starting materials to that found in the output from the molten salt oxidation and salt separation processes as it becomes better characterized, incorporating additional elements and determining their phase distributions, and scaling the process up for use in the Mixed Waste Management Facility.

\section{ACKNOWLEDGMENTS}

This work was initiated by Virginia Oversby. DTA assistance was provided by Philip Ramsey; XRF was performed by Hugh Gregg; ICP-OES and ICP-MS were carried out by Theresa Duewer; James Furr and Vicki Mason-Reed did the sample polishing and ceramography; James Yoshiyama performed SEM-EDS; and Fred Miller and Dominic Del Giudice carried out the XRD. The authors very much appreciate all these efforts. The work was sponsored by the Environmental Restoration and Waste Management Division of the U.S. Department of Energy as part of the Mixed Waste Management Facility project, under the leadership of Ronald Streit, and was performed by Lawrence Livermore National Laboratory under Contract No. W-7405-Eng-48.

\section{REFERENCES}

1. V.M. Oversby, R.A. Van Konynenburg, W.E. Glassley, and P.G. Curtis in Scientific Basis for Nuclear Waste Management XVII, edited by A. Barkatt and R.A. Van Konynenburg (Mater. Res. Soc. Proc. 333, Pittsburgh, PA 1994) pp. 285-292.

2. J.H. Campbell, C.L. Hoenig, F.J. Ackerman, P.E. Peters, and J.Z. Grens in Scientific Basis for Nuclear Waste Management $V$, edited by W. Lutze (Mater. Res. Soc. Proc. 11, North-Holland, New York, NY 1982) pp. 299-308. 
3. F.J. Ryerson, J. Amer. Ceram Soc. 66, 629 (1983).

4. U.S. Environmental Protection Agency, Method 1311 Toxicity Characteristic Leaching Procedure, 40 CFR Part 261.24 and Appendix II, U.S. Code of Federal Regulations, U.S. Govt. Printing Office, Washington, D.C.

5. California Department of Toxic Substances Control, Persistent and Bioaccumulative Toxic Substance (part 66699) and Waste Extraction Test (WET) (part 66700), App. II, Div. 4.5, Title 22, California Code of Regulations, California state government, Sacramento, CA.

6. J. A. Rard, Interim Report on the Volatility and Thermal Stability of Some Halides, Oxyhalides, Oxides, Nitrates, Sulfates, and Other Compounds Relevant to the Synthesis of Ceramic Final Forms for Mixed Waste Immobilization, unpublished report no. L-20722-02, Lawrence Livermore National Laboratory, Livermore, CA.

7. W. Vogel, Glass Chemistry, 2nd Edition, Springer-Verlag, New York, 1994, p. 92.

8. H. Rawson, Inorganic Glass-Forming Systems, Academic Press, New York, 1967, p. 91.

9. U. S. Environmental Protection Agency, 40 CFR Parts 148, 260, 261, 264. 265, 266, 268, and 271: Land Disposal Restrictions Phase II--Universal Treatment Standards, and Treatment Standards for Organic Toxicity Characteristic Wastes and Newly Listed Wastes, Final Rule, Federal Register Vol. 59, No. 180 (September 19, 1994), p. 47982.

10. U.S. Environmental Protection Agency, 40 CFR Parts 148, 268, and 271 Land Disposal Regulations--Phase IV: Issues Associated with Clean Water Act Treatment Equivalency, and Treatment Standards for Wood Preserving Wastes and Toxicity Characteristic Metal Wastes, Proposed Rule, Federal Register Vol. 60, No. 162 9August 22, 1995), p. 43654. 